\title{
Biology of insulin-like growth factor binding protein-4 and its role in cancer (Review)
}

\author{
RAJARAMAN DURAI, MARK DAVIES, WENXUAN YANG, SHI YU YANG, \\ ALEXANDER SEIFALIAN, GEOFFREY GOLDSPINK and MARC WINSLET \\ University Department of Surgery, Royal Free and University College Medical School, \\ University College London, London, UK
}

Received December 23, 2005; Accepted February 17, 2006

\begin{abstract}
Insulin-like growth factor binding protein-4 (IGFBP-4) is an important member of the insulin-like growth factor (IGF) system. The IGFBP-4 has three domains of which the $\mathrm{N}$-terminal sequence is important for the binding of IGF. It acts as a transport protein for IGF-I and IGF-II and modulates their biological effects. There is increasing evidence that IGFBP-4 inhibits IGF-induced cellular growth both in vitro and in vivo. IGFBP-4 can also mediate its actions through a mechanism independent of IGFs. IGFBP-4 level and expression in various tissues are influenced by IGFBP protease, nutrition, several growth factors and hormones. Overexpression of IGFBP-4 in transgenic animal models causes reduced growth of organs containing smooth muscle. Most cancers express IGFBP-4 at levels which correlate with their state of differentiation. However, the effects of IGFBP-4 on tumor growth are uncertain. In vitro studies have shown that overexpression of IGFBP-4 inhibit the growth of some colon cancer cells. Overexpression of IGFBP-4 in vivo has been reported to decrease the growth of prostate cancer. The effect of altered expression of IGFBP-4 in vivo in colon and other cancers needs to be explored as locally available IGFs appear to stimulate mitogenesis.
\end{abstract}

\section{Contents}

1. Introduction

2. Structure and binding characteristics of IGFBP-4

3. Biological actions of IGFBP-4

4. Factors controlling IGFBP-4 expression

5. Role of IGFBP-4 in cancer

Correspondence to: Professor Marc C. Winslet, Division of Surgery and Interventional Sciences, Royal Free and University College Medical School, Hampstead Campus, University College London, Rowland Hill Street, London NW3 2FP, UK

E-mail: m.winslet@medsch.ucl.ac.uk

Key words: insulin-like growth factor, insulin-like growth factor binding protein, cancer
6. Evidence from in vitro studies

7. Evidence from in vivo studies

8. Evidence from population and clinical studies

9. Summary and future recommendations

\section{Introduction}

The insulin-like growth factor system (IGFs) consists of two peptides (IGF-I and -II), two main receptors (IGF-IR and IGFIIR), six different IGF binding proteins (IGFBP1-6) and four IGFBP related peptides (IGFBP Rp1-4). The IGF peptides have a short life-span unless they are bound to a binding protein which transports them in circulation and delivers them to specific tissues. Components of the IGF system are found throughout the body in various fluids and tissues $(1,2)$. IGFs act on a variety of mammalian cells in an endocrine, paracrine and autocrine manner (3) to regulate cell proliferation, apoptosis, transformation and differentiation $(4,5)$. They influence the growth of normal tissue as well as that of several cancers. Most IGFBPs inhibit IGF-induced cell growth by binding to IGFs and acting as a time release mechanism. Some IGFBPs also stimulate cell growth presumably through their own receptors. Hence the IGF system is complex but it provides an interesting example of pre-receptor regulation of cell growth.

Among the IGFBPs, IGFBP-4 is the smallest (1) and it exists in two forms; non-glycosylated $(24 \mathrm{kDa})$ and N-glycosylated forms (28 kDa) (6-8). It occurs in most biological fluids (9). By binding to IGF-I and IGF-II with similar affinities it inhibits their actions under almost all in vitro and in vivo conditions. The glycosylation of IGFBP-4 does not affect its binding to IGF-I (10). The liver is the main source of serum IGFBP-4 (11) but it is abundantly expressed by many tissues including adrenals (12), Leydig cells and interstitial connective tissue of testis (13), the developing embryo, with the notable exceptions of the spinal cord, specific cartilage groups and the thymic cortex (14). The serum level of intact IGFBP-4 is low and is influenced by vitamin D and parathyroid hormone (15). The amount of serum IGFBP-4 shows a positive correlation with age (15). IGFBP-4 is expressed by several cancer cell lines $(7,16,17)$. Overexpression of IGFBP-4 has been shown to reduce the growth of some cancers (18). This review focuses on the physiology of IGFBP-4 and its role in cell growth regulation in different cancers. 


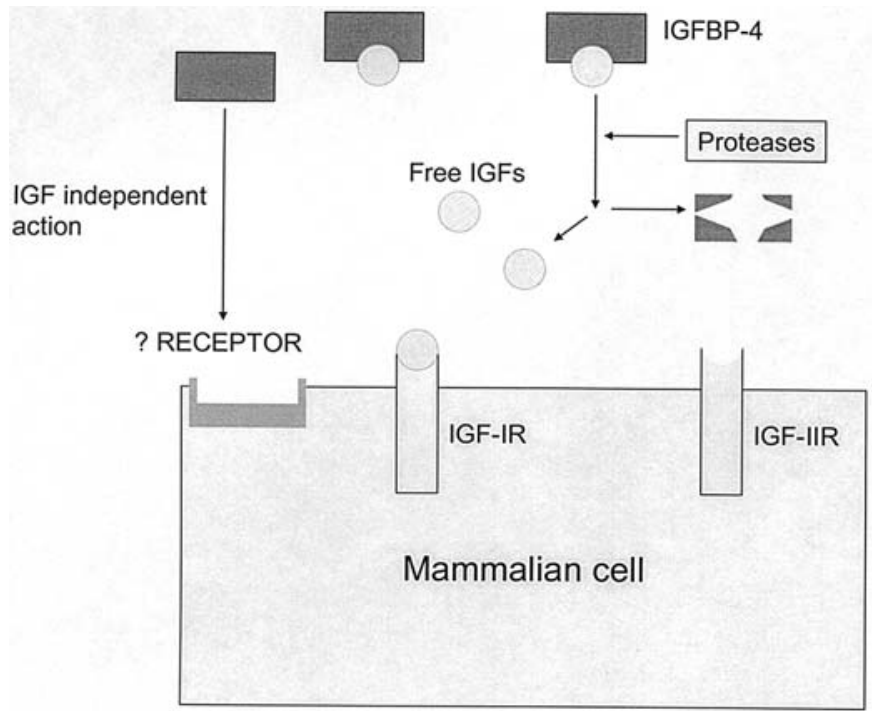

Figure 1. Schematic representation of IGFBP-4 and its interaction with IGF.

\section{Structure and binding characteristics of IGFBP-4}

The gene that encodes IGFBP-4 is located in chromosome region 17q12-q21.1 (19). IGFBP-4 protein has 237 amino acids and 20 cysteines (20). When compared to other IGFBPs, IGFBP-4 has two extra cysteine residues in the variable region encoded by exon 2 (21). IGFBP-4 has three domains $(11,22)$; $\mathrm{N}$-terminal, C-terminal and the central domain. The binding domain of IGF-I and IGF-II involves a hydrophobic motif [Leu (72)-Met (80)] located in the distal part of the conserved $\mathrm{N}$-terminal region. N-terminal Cys residues (Cys9 and Cys12) are more critical than $\mathrm{C}$-terminal Cys residues (Cys17 and Cys20) in affecting IGF-I and IGF-II binding. C-terminal fragments of IGFBP-4 do not bind to IGFs but loss of this fragment decreases the affinity for IGFs. A study (21) showed that deletion of Leu-Ser resulted in loss of both IGF-I and IGF-II binding and substitution of Histidine to Proline abolished both IGF-I and IGF-II binding. This evidence shows that IGFBP-4 has a single binding site for IGF-I and -II.

\section{Biological actions of IGFBP-4}

IGFBP-4 acts by binding to IGF-I and IGF-II and modulating their biological effects (15). IGFBP-4 also has actions independent of IGF-I and IGF-II. Fig. 1 shows the schematic representation of IGFBP-4 and its actions. Local and systemic administrations of IGFBP-4 have different effects. Single local administration of IGFBP-4 over the right parietal bone of the mouse inhibits IGF-I-induced bone formation, whereas systemic administration of IGFBP-4 alone increases serum levels of bone formation markers (23).

Overexpression of IGFBP-4 in transgenic mice resulted in decreased growth of thymus (24), a reduction in weight of smooth muscle rich tissues, including bladder, intestine, aorta, uterus, and stomach, without any change in total body weight $(25,26)$. This indicates that IGFBP-4 is a functional antagonist of IGF-I action on smooth muscle in vivo (26). IGFBP-4 excess also inhibits cell proliferation and stimulates apoptosis in lymphoid tissues but it does not affect lymphocyte development (24). Exogenous IGFBP-4 decreased thrombin-induced DNA synthesis of human aortic vascular smooth muscle cells by $64 \%$, whereas anti-IGFBP-4 antibody potentiated thrombininduced DNA synthesis (27). These data suggest that downregulation of IGFBP-4 expression in vascular smooth muscle plays a critical role in vascular growth response in normal and diseased states, by increasing the bioavailability of IGF-I (27). In addition to its antiproliferative action, IGFBP-4 has been correlated with differentiation of cancer cells (28).

IGF-dependent action. It has been shown that IGFBP-4 inhibits DNA synthesis induced by IGF-I in both cancerous and non-cancerous cells $(29,30)$ but IGFBP-4 has no effect on cell proliferation induced by analogs of IGF-I or IGF-II, which exhibit $>100$-fold reduced affinity for binding to IGFBP-4. The inhibitory action of IGFBP-4 on DNA synthesis occurs in a concentration-dependent manner as evidenced in vascular smooth muscle cells (31). IGFBP-4 inhibits IGF action by preventing the binding of the ligands to IGF-I receptor (32).

$I G F$-independent action. The IGF-independent action of IGFBP-4 is not well understood. In a study (33), when ovarian granulosa cells were incubated with gonadotropins and IGF-I receptor blocker $\alpha$ IR3, IGFBP-4 continued to exert potent inhibitory effects even when the action of endogenous IGF was removed from the system, demonstrating that its actions are independent of IGF binding. In another study (34), IGFBP-4 caused marked $(\mathrm{P}<0.01)$ inhibition of ceramideinduced apoptosis in Hs578T breast cancer cells (34). In IGF-insensitive Isreco-1 cells, reduced colony formation but not cell proliferation and migration was found while IGFBP-4 was overexpressed.

\section{Factors controlling IGFBP-4 expression}

Gene. It has been found that the 1.4-kb pair 5' flanking region of the IGFBP-4 gene containing cis elements is required for the regulation of the IGFBP-4 gene (35). In a recent study, a new binding site known as the Sp3 site has been shown to influence the expression of the IGFBP-4 gene, particularly in CaCo-2 cells $(28,36)$.

Trauma and tissue regeneration. Cerebral contusions increase cortical expression of IGFBP-4 mRNA levels at the contusion site and along the ipsilateral cortex (37). It has been shown that serum IGFBP-4 begins to increase 12-24 h after partial hepatectomy (36), consistent with the increase in corresponding mRNA. These suggest a regulatory mechanism that modulates IGF activity during liver regeneration.

Proteolysis. IGFBP-4 is subject to proteolytic cleavage by several proteases $(38,39)$. One of the IGFBP-4 proteases, also known as pregnancy-associated plasma protein A (PAPP-A) is an important regulator of local IGF bioavailability and cell growth (40). A study conducted in our department on 18 samples of operated colon cancer specimens showed that PAPP-A is expressed by both malignant and non-malignant colon (41). The study also showed that malignant colon expressed less IGFBP-4 than normal colon. This could be 
due to either increased proteolysis in the malignant colon or decreased activity of the IGFBP-4 gene. Colo-205 secretes large quantities of IGFBP-4 but it remains responsive to IGF-I. Analysis of the conditioned medium revealed cleavage of IGFBP-4 into less active fragments which have less affinity, supporting the argument that proteolytic cleavage of IGFBP-4 controls the bioavailability of IGFs (41). Proteases cleave IGFBP-4 into two fragments of approximately 18 and $14 \mathrm{kDa}$, both of which have poor affinity for IGFs $(8,42)$. Sequence analysis of the 14-kDa carboxyl-terminal half of IGFBP-4 suggested cleavage after methionine at position 135 of the mature protein (43). In vivo and in vitro experiments have shown that lysosomal protease cathepsin D and matrix metalloproteinase-7 (44) can also mediate proteolysis (45).

Calorie intake. In a study on rats, stomach IGF-I and IGFBP-4 mRNA levels increased significantly $(\mathrm{P}<0.05)$ when the calorie intake was restricted (46). There were no changes in colonic IGFBP-4 mRNA levels in aged and long-term calorie restricted rats. This indicates that the stomach attempts to preserve IGF activity by increasing local expression of IGF-I and IGFBPs (46). A separate study showed that systemic levels of IGFBP-4 did not change with a low-fat diet (47).

Hormones and growth factors. It appears that several hormones and growth factors may influence the level of IGFBP-4 locally but not enough to alter the levels systemically. These include IGF-I (48), IGF-II (49), oestrogen (50), IL-1ß (51), IL-6 $(51,52)$. IGFBP-4 is apparently not regulated in response to TNF- $\alpha$, PDGF, bFGF, TGF- $\beta$ or the cAMP agonist, forskolin in multiple myeloma cells (49). IGFs may regulate their own availability through proteolytic degradation of IGFBP-4 (53) as attachment of IGFs to IGFBP-4 results in enhancement of proteolysis (54). IGFBP-3 is reported to inhibit IGFBP-4degrading proteinase activity, and binding of IGFs or glycosaminoglycans to IGFBP-3 may induce conformational changes in the binding protein, causing disinhibition of the proteinase (55).

Both growth hormone status and pharmacological dose of glucocorticoids do not affect plasma IGFBP-4 although, apparently, a weak positive relationship exists between plasma IGFBP-4 and parathormone (9). Neither hypothyroidism nor hyperthyroidism influence circulating IGFBP-4 levels (9) but, in a study involving rat hepatocytes, the IGFBP-4 levels were increased in the presence of triiodothyronine (56). Retinoic acid and thyroid hormone act synergistically and increase IGFBP-4 expression in cultured rat hepatocytes (56-58).

\section{Role of IGFBP-4 in cancer}

There is accumulated evidence showing a link between IGFBP-4 and a variety of cancers. Tables I and II summarise the important studies in this area. Several cancer cell lines, including multiple myeloma (49), neuroblastoma $(59,60)$, mesothelioma (61), and cancers of the lung $(16,62,63)$, stomach $(17,64)$, thyroid $(65)$, breast $(50,66-68)$, prostate $(69,70)$ and colon $(71)$, have been reported to express IGFBP-4. The role of IGFBP-4 in cancer is discussed below under three headings; in vitro, in vivo and population based studies.

\section{Evidence from in vitro studies}

Neuroblastoma and glioma. It was found that the rat neuroblastoma cell line secreted both glycosylated and nonglycosylated forms of IGFBP-4 and IGF-II treatment decreased the levels of both forms of IGFBP-4 in the culture media (7). This decrease in the IGFBP-4 expression was dose-dependent and could be blocked IGF-I. Although both IGF-I and IGF-II affected the amount of the IGFBP-4, neither peptide affected the expression of the mRNA of $24 \mathrm{~K}$ IGFBP-4.

Overexpression of intercellular communication gap junction gene connexin 43 in glioma cells resulted in decreased cellular proliferation due to higher production of IGFBP-4 (72). In a different study, IGFBP-4 inhibited the binding of [125I]IGF-I by its receptors and blunted the stimulation of $\left[{ }^{3} \mathrm{H}\right]$ thymidine incorporation by IGF-I. In B104 cells, a rat neuronal cell line, IGFBP-4 is the predominantly secreted IGF binding protein (73). Exposure of B104 monolayer cultures to dexamethasone reduced native IGFBP-4 abundance to $<10 \%$ of that in control medium by $48 \mathrm{~h}$ (73). This was due to increased IGFBP-4 activity induced by dexamethasone. These findings suggest a role for IGFBP-4 in neural and neuroblastoma cell function (6).

Lung cancer. Not all lung cancers have been found to express IGFBP-4. In a study involving 69 human lung carcinoma tissues, $>50 \%(35 / 69)$ of samples were positive for IGFBP-4 mRNA (63). In a cell culture experiment, IGFBP-4 levels diminished with increasing concentrations of IGFs (16) in the culture media of non-small cell lung cancer cells, whereas IGFBP-4-specific mRNA was not changed by IGF-I or IGF-II. Either IGFs may activate an IGFBP-4-specific metalloprotease present in culture media or the binding of IGFs to IGFBP-4 may increase the susceptibility of IGFBP-4 to proteolytic degradation (52).

Endocrine cancers. Both human thyroid follicular and papillary carcinoma cells produce IGFBP-4 $(65,74,75)$. In a cell culture experiment involving two human thyroid follicular carcinoma cell lines (FTC-133 and FTC-236 cells), IGFBP-4 secretion was increased in the presence of thyroid stimulating hormone, forskolin, and epidermal growth factor and was reduced by tetradecanoylphorbol acetate (65).

Nodular and bilateral hyperplasia of the adrenal gland as well as pheochromocytomas showed higher expression of IGFBP-4 mRNA while non-functional adrenal carcinomas expressed less IGFBP-4 mRNA than normal adrenals (76).

Breast cancer. The relationship between IGFBP-4 expression and hormonal receptors in breast cancer is unclear. Figueroa et al studied 40 primary breast tumors (77) and found that all of them expressed IGFBP-4 mRNA and the expression was higher in oestrogen receptor (ER)-positive specimens. In another study on 80 breast cancer specimens, IGFBP-4 positively correlated with both estrogen and progesterone receptors and inversely correlated with synthetic-phase (Sphase) fraction (78) which reflects tumor cellular proliferation. In contrast to these two studies, another study on 47 cancer specimens failed to find any relation between ER content and IGFBP-4 levels (67). In an experiment involving MCF-7 breast 
Table I. In vitro studies linking IGFBP-4 and cancer.

\begin{tabular}{|c|c|c|c|}
\hline Author/Refs. & Cell line/tissue & Cancer site & Result/conclusion \\
\hline Bachrach et al (65) & FTC-133 FTC-236 & Follicular thyroid & IGFBP-4 protein and mRNA were $\uparrow$ by TSH, forskolin and EGF \\
\hline Bernardini et al (101) & SK-N-BE(2) & Neuroblastoma & Retinoic acid $\downarrow$ IGFBP-4 secretion \\
\hline Ceda et al (7) & B104 & Neuroblastoma & IGF-I $\uparrow$ but IGF-II $\downarrow$ expression of both isoforms of IGFBP-4 \\
\hline Cheung et al (73) & B104 & Neuroblastoma & $\begin{array}{l}\text { Dexamethasone } \downarrow \text { native IGFBP-4 and a IGFBP-4 protease } \\
\text { is regulated by glucocorticoids }\end{array}$ \\
\hline Bostedt et al (16) & A549 & Lung & IGF-I $\downarrow$ the concentration of IGFBP-4 \\
\hline Damon et al (18) & M12 & Prostate & $\begin{array}{l}\text { Colony formation was significantly inhibited and there was a } \\
\text { marked delay in tumor formation in animals with } \\
\text { IGFBP-4-transfected cells }(\mathrm{P} \leq 0.01)\end{array}$ \\
\hline Drivdahl et al (97) & ALVA-31 and M12 & Prostate & $\begin{array}{l}\text { Antisense cDNA transfected lines proliferated more slowly } \\
\text { and colony formation in was strongly inhibited }\end{array}$ \\
\hline Yi et al (17) & Tissue & Stomach & IGFBP-4 was expressed in most cell lines \\
\hline Cho et al (102) & HT-29 & Colon & $\begin{array}{l}\text { IGFBP- } 4 \text { was } \downarrow \text { by t10c12 conjugated linoleic acid (CLA), } \\
\text { whereas c9t11 CLA had no effect }\end{array}$ \\
\hline Street et al (51) & $\mathrm{CaCo}-2$ & Colon & $\begin{array}{l}\text { IGFBP-4 secretion } \downarrow \text { with differentiation. IGFBP- } 4 \text { was } \downarrow \text { by } \\
\text { IL-1ß and IL- } 6 \text { treatment }\end{array}$ \\
\hline Dai et al (35) & $\mathrm{CaCo}-2$ & Colon & $\begin{array}{l}\text { 1.4-kb } 5 \text { ' flanking region containing cis elements } \\
\text { regulates the IGFBP- } 4 \text { gene }\end{array}$ \\
\hline Singh et al (103) & $\mathrm{CaCo}-2$ & Colon & IGFBP-4 level varies with differentiation \\
\hline $\begin{array}{l}\text { Culouscou and } \\
\text { Shoyab (104) }\end{array}$ & HT-29 & Colon & Purified and identified IGFBP-4 as a growth inhibitor \\
\hline Singh et al (93) & HT-29 & Colon & $\begin{array}{l}\text { Overexpression of IGFBP- } 4 \text { was not inhibitory to HT- } 29 \text { cells. } \\
\text { Endogenous IGFBP- } 4 \text { was a potent inhibitor of autocrine } \\
\text { effects of endogenous factors (IGF-II) }\end{array}$ \\
\hline Shen and Singh (28) & $\mathrm{CaCo}-2$ & Colon & Sp3 binding site, may regulate the expression of the IGFBP-4 gene \\
\hline Park et al (91) & $\mathrm{CaCo}-2$ & Colon & $\begin{array}{l}\text { Transfection with a human BP-4 cDNA exhibited a } 60 \% \\
\text { increase in IGFBP- } 4 \text { mRNA, and secreted twice as much } \\
\text { IGFBP-4 protein as controls. IGFBP-4-overexpressing } \\
\text { cells proliferated at only } 25 \% \text { the rate of control }\end{array}$ \\
\hline Corkins et al (94) & HT-29 & Colon & Cell differentiation correlates with an $\uparrow$ in IGFBP-4 levels \\
\hline Diehl et al (90) & Isreco-1, LS1034 & Colon & $\begin{array}{l}\text { In IGF-insensitive Isreco- } 1 \text { cells, overexpression of IGFBP- } 4 \downarrow \\
\text { colony formation but not cell proliferation and migration. } \\
\text { In IGF-dependent LS1034 cells, IGFBP-4 inhibited all } \\
\text { parameters of growth tested }\end{array}$ \\
\hline Pratt and Pollak (82) & MCF-7 & Breast & Antiestrogens and tamoxifen $\downarrow$ levels of IGFBP-4 \\
\hline Gronbaek et al (83) & Human & Breast & IGFBP- $4 \downarrow$ before and $\uparrow$ during Tamoxifen treatment \\
\hline Coutts et al (81) & $\mathrm{T}-47 \mathrm{D}$ & Breast & $\begin{array}{l}\text { Medroxyprogesterone acetate } \downarrow \text { IGFBP-4, antiestrogen ICI } \\
164384 \text { transiently } \downarrow \text { mRNA of IGFBP-4 }\end{array}$ \\
\hline Chen et al (79) & MCF-7 & Breast & IGFBP-4 had no effect on IGF-I induced DNA synthesis \\
\hline Perks et al (34) & Hs578T & Breast & $\begin{array}{l}\text { IGFBP- } 4 \text { caused marked }(\mathrm{P}<0.01) \text { inhibition of } \\
\text { ceramide-induced apoptosis. }\end{array}$ \\
\hline
\end{tabular}


Table II. In vivo, clinical and population studies on the relationship between IGFBP-4 and cancer.

\begin{tabular}{|c|c|c|c|c|}
\hline Author/Refs. & Model & Cell line & Cancer site & Outcome \\
\hline Damon et al (18) & Nude mice & M12 & Prostate & $\begin{array}{l}\text { Marked delay of tumor formation in animals receiving } \\
\text { IGFB-4 transfected cells }\end{array}$ \\
\hline Drivdahl et al (97) & Nude mice & $\begin{array}{l}\text { ALVA-31 } \\
\text { and M12 }\end{array}$ & Prostate & $\begin{array}{l}\text { The rate of tumor formation and growth in male athymic } \\
\text { nude mice injected with M12asBP4 was markedly }\end{array}$ \\
\hline Gronbaek et al (83) & Human & NA & Breast & IGFBP- $4 \downarrow$ before and $\uparrow$ during Tamoxifen treatment \\
\hline $\mathrm{Ng}$ et al (99) & $\begin{array}{l}63 \text { breast cancer pts and } \\
27 \text { benign breast disease }\end{array}$ & NA & Breast & $\begin{array}{l}\text { Decreasing levels of IGFBP-4 }(\mathrm{P}<0.01) \text { was associated } \\
\text { with positivity of progesterone receptors in the tumor }\end{array}$ \\
\hline
\end{tabular}

$\uparrow$, increase; $\downarrow$, decrease; NA, not applicable.

cancer cells, IGFBP-4 had no effect on IGF-I-induced DNA synthesis (79) but, in Hs578T breast cancer cells, IGFBP-4 caused marked $(\mathrm{P}<0.01)$ inhibition of ceramide-induced apoptosis (34).

The expression of IGFBP-4 in breast cancer is modulated by various hormones. Treatment of $\mathrm{MCF}-7$ cells with an estrogen, 17ß-estradiol, resulted in increased IGFBP-4 gene expression ( $>3$-fold) and protein secretion ( $>6$-fold) (80). Further evidence showed that antiestrogens ICI 164384 and ICI 182780 decreased mRNA levels of IGFBP-4 $(81,82)$. In $\mathrm{N}$-nitrosomethylurea-induced rat mammary tumor, IGFBP-4 mRNAs decreased with ovariectomy and increased with hormone repletion. Another anti-estrogen, tamoxifen, significantly reduces the levels of IGFBP-4 protein in the conditioned medium of MCF7 cells (82). But a small study on 8 patients showed an increase in serum IGFBP-4 levels after tamoxifen (83), which may reflect the systemic effect of tamoxifen.

In a different study, medroxyprogesterone acetate treatment resulted in a time- and dose-dependent decrease in IGFBP-4 mRNA but mifepristone alone had little or no effect (81). A synthetic progestin, Org2058, but not dexamethasone, inhibited IGFBP-4 expression. In a separate study, IGFBP-4 levels were slightly decreased in response to high doses of human chorionic gonadotropin (84).

It has been shown that retinoic acid increases the IGFBP-4 level in conditioned medium in the MCF-7 breast carcinoma cell line (85). In contrast, another study shows that retinoic acid reduces transcriptional activity of the IGFBP-4 gene (86). Retinoic acid and estrogen increased IGFBP-4 mRNA levels in many ER-positive cell lines and the effect of oestrogen and retinoic acid in combination was additive (50). Although both of them individually enhanced IGFBP-4 mRNA levels in ER-positive T47D cells, their effect in combination was antagonistic in this cell line (50). Transfection of human ER into ER-negative MDA-MB-231 cells conferred retinoic acid and oestrogen the ability to enhance IGFBP-4 mRNA but both agents failed to concomitantly modulate IGFBP-4 levels in the CM suggesting a dual regulation by these agents at transcription/post-transcription and translation/secretion levels (50).
Osteosarcoma and multiple myeloma. Normal osteoblasts secrete IGFBP-4 as well as an IGF-dependent IGFBP-4 protease (39). Therefore, the IGF system can influence bone growth by altering the levels of IGFBPs and thereby influencing free IGFs. Fully tumorigenic osteosarcoma cells do not express IGFBP-4 as well as an IGF-dependent IGFBP-4 protease (39).

Human myeloma cells express IGFBP-4 (49). In late stages of myeloma, there is increased bone destruction and decreased bone formation, which causes osteolytic lesions. This may be due to multiple myeloma cells secreting IGFBP-4, which inhibits IGF-I-stimulated bone formation by adjacent normal osteoblasts (49).

Genitourinary cancers. Ovarian carcinomas frequently express IGFBP-4 (87) but the precise role of IGFBP-4 is yet to be evaluated. A recent study found that IGFBP- 4 mRNA is down-regulated in seminomas and oncocytomas which may enhance IGF stimulated growth of cancer cells $(88,89)$.

Gastrointestinal cancers. The majority of colon cancers studied were found to express IGFBP-4 (35,70). In an in vitro study, Diehl et al (90) found overexpressed IGFBP-4 in colon cancer cells when using murine IGFBP-4 cDNA. Overexpression of IGFBP-4, in IGF-insensitive colon (Isreco) cells, decreased the colony formation alone without any effect on cell proliferation and migration but, in IGF-dependent LS1034 cells, it decreased proliferation, migration and colony formation, although IGF-II partly restored the first two parameters. In another IGF-sensitive cell, Isreco-2, which lacks endogenous IGF expression, the colony formation was decreased by IGFBP-4. In a different study (91), CaCo-2 cells were transfected with a human IGFBP-4 cDNA construct and they exhibited a $60 \%$ increase in IGFBP-4 mRNA and secreted twice as much IGFBP-4 protein as in controls. The IGFBP-4 overexpressing cells proliferated at only $25 \%$ of the rate of control cells in serum-free medium and there was a $70 \%$ increase in expression of sucrase-isomaltase (91). IGFBP-4 gene expression played an important role in the transition from proliferation to differentiation in colon cancer cell line, CaCo-2 (28). IGFBP-4 expression in CaCo-2 cells correlated 
well with cell differentiation (92) and a significant upregulation of IGFBP-4 expression occured on spontaneous differentiation in culture (35).

Antisense inhibition of IGFBP-4 mRNA confers a growth advantage to the cells in response to endogenous and exogenous IGFs (35). Dai et al (35) studied the inhibitory role of endogenous IGFBP-4 on HT-29 human colon cancer cells. Both the basal and IGF-stimulated growth of cells were significantly increased over control values in the presence of IGFBP-4 antibody, suggesting that endogenous IGFBP-4 is a potent inhibitor of the mitogenic effects of endogenous and exogenous IGFs (93). Singh et al (93) also transfected colon cancer cells with sense and antisense cDNA fragments of human IGFBP-4. The basal and IGF-I-stimulated growth of antisense cells were significantly higher than those of control and sense cells. The basal and IGF-I-stimulated growth of sense cells were not significantly different from those of the control cells, suggesting that overexpression of IGFBP-4 was not inhibitory to the growth of HT-29 cells.

HT29-D4 cells secreted IGF-II which became totally complexed to IGFBP-2, IGFBP-4 and IGFBP-6 and $15 \%$ of IGFBP-4 was associated with the extracellular matrix (42). IGFBP-4 proteolysis by cell-bound plasmin can promote autocrine/paracrine IGF-II bio-availability in colon cancer cells (42). Corkins and co-workers (94) studied the effect of carbohydrate on expression of IGFBP-4 by HT-29 cells. The cells were grown in either glucose or galactose (glucose free) medium. Cells grown in galactose medium showed low IGFBP-4 levels until they approached confluence, at which point the levels increased significantly, while the cells grown in glucose medium showed increasing IGFBP-4 levels with increasing cell number, except for a transient decrease at confluence. HT-29 cells, when treated with retinoic acid, had dose-dependent increases in IGFBP-4 and reduced IGF-II expression. In a different study, HT-29 cells were treated with IGF-I for various time periods, which resulted in increased VEGF mRNA expression. When the activity of IGFBP-4 was blocked, it did not significantly influence the effect of IGF-I induction of VEGF mRNA in HT-29 cells (95).

A previous study conducted in our department to assess the expression of IGFBP-4 protein in malignant and nonmalignant colonic tissue in 18 patients, showed significantly lower amounts of IGFBP-4 in colon cancer than in nonmalignant colon in 16 patients $(\mathrm{P}<0.05)$, which was confirmed by Western blotting and immunohistochemistry (41). This may be due to the increased protease activity of transgenic cells.

Expression of IGFBP-4 has also been found in most gastric carcinoma cell lines $(17,64)$ but it is important to distinguish between increased expression at the mRNA level and the concentration of the protein. Regrettably, this is often overlooked as the functional aspects of IGFBP-4 are dependent on the protein.

Prostate cancer. Prostate carcinoma cells secrete IGFBP-4 $(69,96)$, as well as a general IGFBP protease and cathepsin D, both of which are capable of hydrolyzing all endogenous IGFBPs and, thus, modifying IGF-I action in prostatic cells (69). In one study, IGFBP-4 was overexpressed by transfecting malignant M12 prostate epithelial cells with plasmid containing IGFBP-4 (18). Consequently, IGF-induced proliferation was reduced in the IGFBP-4 transfected cells compared with control cells $(\mathrm{P} \leq 0.01)$. Colony formation in soft agar was inhibited for 14 days $(\mathrm{P} \leq 0.01)$. As IGFBP-4 has been suggested to inhibit cell growth, the reduction of IGFBP-4 expression should increase the availability of free IGFs, which would increase cell growth. In reality, the results were different. In another study (97), when IGFBP-4 expression was inhibited with antisense cDNA in two prostate tumor cell lines, ALVA-31 and M12, both transfected lines proliferated more slowly in monolayer culture than parental controls. Colony formation in soft agar was strongly inhibited in both cases. Apoptosis induced by the topoisomerase inhibitor, etoposide, was also enhanced in transfected cells. The results may be due to the involvement of other binding proteins which influence cell growth.

\section{Evidence from in vivo studies}

When compared to in vitro studies the numbers of in vivo studies which demonstrate the effect of IGFBP-4 in cancer are much fewer and less well standardised.

Hepatocellular carcinoma. IGFBP-4 expression in preneoplastic and neoplastic lesions is not the same. Immunohistochemical studies showed increased expression of IGF-I and IGFBP-4 in preneoplastic lesions (98). Hepatocellular carcinoma arising in this lesion showed decreased expression of IGF-I and IGFBP-4. The altered gene expression in glycogen-storing preneoplastic hepatic foci, especially the up-regulation of IGF-I and IGFBP-4 with the down-regulation of IGFBP-1, resembles the insulin-dependent regulation of these components in normal rat hepatocytes.

Prostate cancer. Damon et al (18) transfected prostate cancer cells with the IGFBP-4 gene and injected these cells subcutaneously into male athymic/nude mice. There was a marked delay in tumor formation in animals receiving IGFBP-4 transfected cells when compared with controls. In a reverse experiment, when IGFBP-4 expression was inhibited with antisense cDNA in prostate tumor cell line, M12, it also markedly reduced the rate of tumor formation and growth in male athymic nude mice (97). These studies demonstrated that the in vivo effect of altered expression of IGFBP-4 is complex and is under the influence of several unknown factors.

\section{Evidence from population and clinical studies}

In a case-control study (99) involving 63 breast cancer patients, decreasing serum levels of IGFBP-4 $(\mathrm{P}<0.01)$ were significantly associated with an increasing number of progesterone receptors in the tumor. IGFBP-4 was significantly $(\mathrm{P}<0.01)$ associated with the risk of breast cancer.

In one study, the IGFBP-4 levels in the circulation did not show any difference in most of the cancer patients with solid tumors, although several children with acute lymphoblastic leukaemia showed increased plasma IGFBP-4 levels (9).

In a phase II clinical trial, it was found that the plasma levels of IGFBP-4 were not significantly affected by the administration of suramin, a drug used for African trypanosomiasis, but free IGF-I plasma levels were consistently increased over $250 \%$ in patients with advanced breast cancer (100). 


\section{Summary and future recommendations}

IGFBP-4 acts mainly by sequestering the IGFs and is a very important inhibitory binding protein of the IGF system. IGFBP4 levels and expression by various tissues are influenced by IGFBP protease, nutrition, trauma, several growth factors and hormones. IGFBP-4 mRNA expression is not necessarily a good indicator of the amount of IGFBP-4 associated with the cells. Although several types of cancer cell express IGFBP-4 and its role has been widely studied in breast cancer, the results are controversial. In vitro and in vivo studies have shown that overexpression of IGFBP-4 is inhibitory to many cancer cells, though there are exceptions; however, reduced expression of IGFBP-4 may not increase cell growth in some cancers; for example, prostatic cancer. In colorectal cancer, antisense inhibition of IGFBP-4 may confer a growth advantage while overexpression of IGFBP-4 may not be inhibitory to some colon cancer cells. To date, there are only two studies of prostate cancer that have shown the effect of IGFBP-4 in vivo. Apart from the one study conducted by Damon et al (18), there is no other in vivo evidence that IGFBP-4 overexpression is inhibitory to cancers. The following questions need to be addressed: i) do all types of cancer cell fail to produce appropriate levels of IGFBP-4 and, if so, is this due to increased secretion of protease? ii) does systemically introduced IGFBP-4 have serious side effects as IGFs are involved in many physiological reactions? Further in vitro and in vivo studies are advisable before considering the clinical use of IGFBP-4

\section{References}

1. Zhou R, Diehl D, Hoeflich A, Lahm H and Wolf E: IGFbinding protein-4: biochemical characteristics and functional consequences. J Endocrinol 178: 177-193, 2003.

2. Rajaram S, Baylink DJ and Mohan S: Insulin-like growth factor-binding proteins in serum and other biological fluids: regulation and functions. Endocr Rev 18: 801-831, 1997.

3. Grimberg ACP: Role of insulin-like growth factors and their binding proteins in growth control and carcinogenesis. J Cell Physiol 183: 1-9, 2000.

4. Leng SL, Leeding KS, Whitehead RH and Bach LA: Insulinlike growth factor (IGF)-binding protein-6 inhibits IGF-IIinduced but not basal proliferation and adhesion of LIM 1215 colon cancer cells. Mol Cell Endocrinol 174: 121-127, 2001.

5. Moschos SJ and Mantzoros CS: The role of the IGF system in cancer: from basic to clinical studies and clinical applications. Oncology 63: 317-332, 2002.

6. Cheung PT, Smith EP, Shimasaki S, Ling N and Chernausek SD: Characterization of an insulin-like growth factor binding protein (IGFBP-4) produced by the B104 rat neuronal cell line: chemica and biological properties and differential synthesis by sublines. Endocrinology 129: 1006-1015, 1991

7. Ceda GP, Fielder PJ, Henzel WJ, Louie A, Donovan SM, Hoffman AR and Rosenfeld RG: Differential effects of insulinlike growth factor (IGF)-I and IGF-II on the expression of IGF binding proteins (IGFBPs) in a rat neuroblastoma cell line: isolation and characterization of two forms of IGFBP-4. Endocrinology 128: 2815-2824, 1991

8. Kelley KM, Oh Y, Gargosky SE, Gucev Z, Matsumoto T, Hwa V, Ng L, Simpson DM and Rosenfeld RG: Insulin-like growth factor-binding proteins (IGFBPs) and their regulatory dynamics. Int J Biochem Cell Biol 28: 619-637, 1996

9. Van Doorn J, Cornelissen AJ and van Buul-Offers SC: Plasma levels of insulin-like growth factor binding protein-4 (IGFBP-4) under normal and pathological conditions. Clin Endocrinol 54: 655-664, 2001

10. Chelius D, Baldwin MA, Lu X and Spencer EM: Expression, purification and characterization of the structure and disulfide linkages of insulin-like growth factor binding protein-4. J Endocrinol 168: 283-296, 2001.
11. Mazerbourg S, Callebaut I, Zapf J, Mohan S, Overgaard M and Monget P: Update on IGFBP-4: regulation of IGFBP-4 levels and functions, in vitro and in vivo. Growth Horm IGF Res 14: $71-84,2004$

12. Ilvesmaki V, Blum WF and Voutilainen R: Insulin-like growth factor binding proteins in the human adrenal gland. Mol Cell Endocrinol 97: 71-79, 1993.

13. Zhou J and Bondy C: Anatomy of the insulin-like growth factor system in the human testis. Fertil Steril 60: 897-904, 1993

14. Cerro JA, Grewal A, Wood TL and Pintar JE: Tissue-specific expression of the insulin-like growth factor binding protein (IGFBP) mRNAs in mouse and rat development. Regul Pept 48: 189-198, 1993

15. Honda Y, Landale EC, Strong DD, Baylink DJ and Mohan S Recombinant synthesis of insulin-like growth factor-binding protein-4 (IGFBP-4): development, validation, and application of a radioimmunoassay for IGFBP-4 in human serum and other biological fluids. J Clin Endocrinol Metab 81: 1389-1396, 1996.

16. Bostedt KT, Schmid C, Ghirlanda-Keller C, Olie R, Winterhalter KH and Zapf J: Insulin-like growth factor (IGF) I down-regulates type 1 IGF receptor (IGF-1R) and reduces the IGF-I response in A549 non-small cell lung cancer and Saos-2/ B-10 osteoblastic osteosarcoma cells. Exp Cell Res 271: 368-377, 2001

17. Yi HK, Hwang PH, Yang DH, Kang CW and Lee DY: Expression of the insulin-like growth factors (IGFs) and the IGF-binding proteins (IGFBPs) in human gastric cancer cells. Eur J Cancer 37: 2257-2263, 2001.

18. Damon SE, Maddison L, Ware JL and Plymate SR: Overexpression of an inhibitory insulin-like growth factor binding protein (IGFBP), IGFBP-4, delays onset of prostate tumor formation. Endocrinology 139: 3456-3464, 1998.

19. Tonin P, Ehrenborg E, Lenoir G, Feunteun J, Lynch H, Morgan K, Zazzi H, Vivier A, Pollak M, Huynh H, et al: The human insulinlike growth factor-binding protein 4 gene maps to chromosome region $17 \mathrm{q} 12-\mathrm{q} 21.1$ and is close to the gene for hereditary breastovarian cancer. Genomics 18: 414-417, 1993.

20. Hwa V, Oh Y and Rosenfeld RG: The insulin-like growth factor-binding protein (IGFBP) superfamily. Endocr Rev 20: 761-787, 1999

21. Qin X, Strong DD, Baylink DJ and Mohan S: Structure-function analysis of the human insulin-like growth factor binding protein-4. J Biol Chem 273: 23509-23516, 1998.

22. Fernandez-Tornero C, Lozano RM, Rivas G, Jimenez MA, Standker L, Diaz-Gonzalez D, Forssmann WG, Cuevas P, Romero A and Gimenez-Gallego G: Synthesis of the blood circulating C-terminal fragment of insulin-like growth factor (IGF)-binding protein- 4 in its native conformation. Crystallization, heparin and IGF binding, and osteogenic activity. J Biol Chem 280: 18899-18907, 2005.

23. Miyakoshi N, Richman C, Qin X, Baylink DJ and Mohan S: Effects of recombinant insulin-like growth factor-binding protein- 4 on bone formation parameters in mice. Endocrinology 140: 5719-5728, 1999.

24. Zhou R, Flaswinkel H, Schneider MR, Lahm H, Hoeflich A, Wanke R and Wolf E: Insulin-like growth factor-binding protein- 4 inhibits growth of the thymus in transgenic mice. J Mol Endocrinol 32: 349-364, 2004.

25. Schneider MR, Lahm H, Wu M, Hoeflich A and Wolf E: Transgenic mouse models for studying the functions of insulinlike growth factor-binding proteins. FASEB J 14: 629-640, 2000.

26. Wang J, Niu W, Witte DP, Chernausek SD, Nikiforov YE, Clemens TL, Sharifi B, Strauch AR and Fagin JA: Overexpression of insulin-like growth factor-binding protein-4 (IGFBP-4) in smooth muscle cells of transgenic mice through a smooth muscle alpha-actin-IGFBP-4 fusion gene induces smooth muscle hypoplasia. Endocrinology 139: 2605-2614, 1998.

27. Anwar A, Zahid AA, Phillips L and Delafontaine P: Insulinlike growth factor binding protein-4 expression is decreased by angiotensin II and thrombin in rat aortic vascular smooth muscle cells. Arterioscler Thromb Vasc Biol 20: 370-376, 2000.

28. Shen Q and Singh P: Identification of a novel SP3 binding site in the promoter of human IGFBP4 gene: role of SP3 and AP-1 in regulating promoter activity in $\mathrm{CaCo} 2$ cells. Oncogene 23 : $2454-2464,2004$

29. Clemmons DR: IGF binding proteins: regulation of cellular actions. Growth Regul 2: 80-87, 1992.

30. Hsieh T, Gordon RE, Clemmons DR, Busby WH Jr and Duan C: Regulation of vascular smooth muscle cell responses to insulinlike growth factor (IGF)-I by local IGF-binding proteins. J Biol Chem 278: 42886-42892, 2003. 
31. Duan C and Clemmons DR: Differential expression and biological effects of insulin-like growth factor-binding protein-4 and -5 in vascular smooth muscle cells. J Biol Chem 273: 16836-16842, 1998.

32. Mohan S, Nakao Y, Honda Y, Landale E, Leser U, Dony C, Lang K and Baylink DJ: Studies on the mechanisms by which insulin-like growth factor (IGF) binding protein-4 (IGFBP-4) and IGFBP-5 modulate IGF actions in bone cells. J Biol Chem 270: 20424-20431, 1995.

33. Wright RJ, Holly JM, Galea R, Brincat M and Mason HD: Insulin-like growth factor (IGF)-independent effects of IGF binding protein-4 on human granulosa cell steroidogenesis. Biol Reprod 67: 776-781, 2002

34. Perks CM, Bowen S, Gill ZP, Newcomb PV and Holly JM: Differential IGF-independent effects of insulin-like growth factor binding proteins (1-6) on apoptosis of breast epithelial cells. J Cell Biochem 75: 652-664, 1999.

35. Dai B, Widen SG, Mifflin R and Singh P: Cloning of the functional promoter for human insulin-like growth factor binding protein-4 gene: endogenous regulation. Endocrinology 138: 332-343, 1997.

36. Demori I, Balocco S, Voci A and Fugassa E: Increased insulinlike growth factor binding protein-4 expression after partial hepatectomy in the rat. Am J Physiol 278: 384-389, 2000.

37. Nordqvist AC, Holmin S, Nilsson M, Mathiesen T and Schalling M: MK-801 inhibits the cortical increase in IGF-1, IGFBP-2 and IGFBP-4 expression following trauma. Neuroreport 8: 455-460, 1997.

38. Byun D, Mohan S, Kim C, Suh K, Yoo M, Lee H, Baylink DJ and Qin X: Studies on human pregnancy-induced insulin-like growth factor (IGF)-binding protein-4 proteases in serum: determination of IGF-II dependency and localization of cleavage site. J Clin Endocrinol Metab 85: 373-381, 2000.

39. Durham SK, Riggs BL, Harris SA and Conover CA: Alterations in insulin-like growth factor (IGF)-dependent IGF-binding protein-4 proteolysis in transformed osteoblastic cells. Endocrinology 136: 1374-1380, 1995.

40. Chen BK, Overgaard MT, Bale LK, Resch ZT, Christiansen M, Oxvig C and Conover CA: Molecular regulation of the IGFbinding protein-4 protease system in human fibroblasts: identification of a novel inducible inhibitor. Endocrinology 143: 1199-1205, 2002.

41. Davies M: Characterisation of the Insulin-Like Growth Factor System in Human Colorectal Tissue. University College London, Thesis, 2004.

42. Remacle-Bonnet MM, Garrouste FL and Pommier GJ: Surfacebound plasmin induces selective proteolysis of insulin-likegrowth-factor (IGF)-binding protein-4 (IGFBP-4) and promotes autocrine IGF-II bio-availability in human colon-carcinoma cells. Int J Cancer 72: 835-843, 1997.

43. Conover CA, Durham SK, Zapf J, Masiarz FR and Kiefer MC: Cleavage analysis of insulin-like growth factor (IGF)-dependent IGF-binding protein-4 proteolysis and expression of proteaseresistant IGF-binding protein-4 mutants. J Biol Chem 270: 4395-4400, 1995.

44. Nakamura M, Miyamoto S, Maeda H, Ishii G, Hasebe T, Chiba T, Asaka $M$ and Ochiai A: Matrix metalloproteinase-7 degrades all insulin-like growth factor binding proteins and facilitates insulinlike growth factor bioavailability. Biochem Biophys Res Commun 333: 1011-1016, 2005.

45. Braulke T, Claussen M, Saftig P, Wendland M, Neifer K, Schmidt B, Zapf J, von Figura K and Peters C: Proteolysis of IGFBPs by cathepsin D in vitro and in cathepsin D-deficient mice. Prog Growth Factor Res 6: 265-271, 1995.

46. Hallberg LM, Ikeno Y, Englander E and Greeley GH Jr: Effects of aging and caloric restriction on IGF-I, IGF-I receptor, IGFBP-3 and IGFBP-4 gene expression in the rat stomach and colon. Regul Pept 89: 37-44, 2000.

47. Ngo TH, Barnard RJ, Cohen P, Freedland S, Tran C, De Gregorio F, Elshimali YI, Heber D and Aronson WJ: Effect of isocaloric low-fat diet on human LAPC-4 prostate cancer xenografts in severe combined immunodeficient mice and the insulinlike growth factor axis. Clin Cancer Res 9: 2734-2743, 2003.

48. Price WA, Moats-Staats BM and Stiles AD: Insulin-like growth factor-I (IGF-I) regulates IGFBP-3 and IGFBP-4 by multiple mechanisms in A549 human adenocarcinoma cells. Am J Respir Cell Mol Biol 13: 466-476, 1995.

49. Feliers D, Woodruff K and Abboud S: Potential role of insulinlike growth factor binding protein- 4 in the uncoupling of bone turnover in multiple myeloma. Br J Haematol 104: 715-722, 1999.
50. Sheikh MS, Shao ZM, Hussain A, Chen JC, Roberts CT Jr, Le Roith D and Fontana JA: Retinoic acid and estrogen modulation of insulin-like growth factor binding protein-4 gene expression and the estrogen receptor status of human breast carcinoma cells. Biochem Biophys Res Commun 193: 1232-1238, 1993.

51. Street ME, Miraki-Moud F, Sanderson IR, Savage MO, Giovannelli G, Bernasconi S and Camacho-Hubner C: Interleukin-1beta (IL-1beta) and IL-6 modulate insulin-like growth factor-binding protein (IGFBP) secretion in colon cancer epithelial (Caco-2) cells. J Endocrinol 179: 405-415, 2003.

52. Fernandez-Celemin L and Thissen JP: Interleukin-6 stimulates hepatic insulin-like growth factor binding protein-4 messenger ribonucleic acid and protein. Endocrinology 142: 241-248, 2001.

53. Noll K, Wegmann BR, Havemann K and Jaques G: Insulin-like growth factors stimulate the release of insulin-like growth factorbinding protein-3 (IGFBP-3) and degradation of IGFBP-4 in non-small cell lung cancer cell lines. J Clin Endocrinol Metab 81: 2653-2662, 1996.

54. Clemmons DR: IGF binding proteins and their functions. Mol Reprod Dev 35: 368-374, 1993.

55. Fowlkes JL, Serra DM, Rosenberg CK and Thrailkill KM: Insulin-like growth factor (IGF)-binding protein-3 (IGFBP-3) functions as an IGF-reversible inhibitor of IGFBP-4 proteolysis. J Biol Chem 270: 27481-27488, 1995.

56. Demori I, Bottazzi C, Arzani D, Voci A and Fugassa E: Regulation of IGFBP-1 and -4 expression by triiodothyronine (T3) in cultured hepatocytes is cell- and gene-specific. Boll Soc Ital Biol Sper 73: 47-53, 1997.

57. Demori I, Bottazzi C, Voci A, Gallo G, Scharf JG and Fugassa E: Tri-iodothyronine increases insulin-like growth factor binding protein-4 expression in rat hepatocytes. J Endocrinol 154: 155-165, 1997.

58. Demori I, Balocco S, Gerdoni E, Fugassa E and Voci A: Retinoic acid increases insulin-like growth factor-binding protein-4 expression in cultured rat hepatocytes. Horm Metab Res 36: 7-13, 2004

59. Babajko S and Binoux M: Modulation by retinoic acid of insulinlike growth factor (IGF) and IGF binding protein expression in human SK-N-SH neuroblastoma cells. Eur J Endocrinol 134: 474-480, 1996.

60. Babajko S, Leneuve P, Loret $\mathrm{C}$ and Binoux M: IGF-binding protein-6 is involved in growth inhibition in SH-SY5Y human neuroblastoma cells: its production is both IGF- and cell densitydependent. J Endocrinol 152: 221-227, 1997.

61. Hodzic D, Delacroix L, Willemsen P, Bensbaho K, Collette J, Broux R, Lefebvre P, Legros JJ, Grooteclaes M and Winkler R: Characterization of the IGF system and analysis of the possible molecular mechanisms leading to IGF-II over-expression in a mesothelioma. Horm Metab Res 29: 549-555, 1997.

62. Wegmann BR, Schoneberger HJ, Kiefer PE, Jaques G, Brandscheid D and Havemann K: Molecular cloning of IGFBP-5 from SCLC cell lines and expression of IGFBP-4, IGFBP-5 and IGFBP-6 in lung cancer cell lines and primary tumours. Eur J Cancer 29A: 1578-1584, 1993.

63. Pavelic J, Pavelic L, Karadza J, Krizanac S, Unesic J, Spaventi S and Pavelic K: Insulin-like growth factor family and combined antisense approach in therapy of lung carcinoma. Mol Med 8: 149-157, 2002.

64. Guo YS, Beauchamp RD, Jin GF, Townsend CM Jr and Thompson JC: Insulin-like growth factor-binding protein modulates the growth response to insulin-like growth factor 1 by human gastric cancer cells. Gastroenterology 104: 1595-1604, 1993.

65. Bachrach LK, Nanto-Salonen K, Tapanainen P, Rosenfeld RG and Gargosky SE: Insulin-like growth factor binding protein production in human follicular thyroid carcinoma cells. Growth Regul 5: 109-118, 1995.

66. Sheikh MS, Shao ZM, Clemmons DR, Le Roith D, Roberts CT Jr and Fontana JA: Identification of the insulin-like growth factor binding proteins 5 and 6 (IGFBP-5 and -6) in human breast cancer cells. Biochem Biophys Res Commun 183: 1003-1010, 1992.

67. Pekonen F, Nyman T, Ilvesmaki V and Partanen S: Insulin-like growth factor binding proteins in human breast cancer tissue. Cancer Res 52: 5204-5207, 1992.

68. McGuire WL Jr, Jackson JG, Figueroa JA, Shimasaki S, Powell DR and Yee D: Regulation of insulin-like growth factorbinding protein (IGFBP) expression by breast cancer cells: use of IGFBP-1 as an inhibitor of insulin-like growth factor action. J Natl Cancer Inst 84: 1336-1341, 1992. 
69. Conover CA, Perry JE and Tindall DJ: Endogenous cathepsin Dmediated hydrolysis of insulin-like growth factor-binding proteins in cultured human prostatic carcinoma cells. J Clin Endocrinol Metab 80: 987-993, 1995.

70. Srinivasan N, Edwall D, Linkhart TA, Baylink DJ and Mohan S: Insulin-like growth factor-binding protein-6 produced by human PC-3 prostate cancer cells: isolation, characterization and its biological action. J Endocrinol 149: 297-303, 1996.

71. Michell NP, Langman MJ and Eggo MC: Insulin-like growth factors and their binding proteins in human colonocytes: preferential degradation of insulin-like growth factor binding protein 2 in colonic cancers. Br J Cancer 76: 60-66, 1997.

72. Bradshaw SL, Naus CC, Zhu D, Kidder GM and Han VK: Insulin-like growth factor binding protein-4 gene expression is induced by transfection of gap junction connexin 43 gene in a C6 glioma cell line. Growth Regul 3: 26-29, 1993

73. Cheung PT, Wu J, Banach W and Chernausek SD: Glucocorticoid regulation of an insulin-like growth factor-binding protein-4 protease produced by a rat neuronal cell line. Endocrinology 135: 1328-1335, 1994.

74. Isozaki O, Tsushima T, Ohmura E, Onoda N, Demura H, Sato Y, Shizume K and Yashiro T: Expression of insulinlike growth factor binding proteins (IGFBPs) in human thyroid papillary cancer tissues. Endocr J 43 (Suppl): 97-98, 1996.

75. Van der Laan BF, Freeman JL and Asa SL: Expression of growth factors and growth factor receptors in normal and tumorous human thyroid tissues. Thyroid 5: 67-73, 1995.

76. Ilvesmaki V, Liu J, Heikkila P, Kahri AI and Voutilainen R: Expression of insulin-like growth factor binding protein 1-6 genes in adrenocortical tumors and pheochromocytomas. Horm Metab Res 30: 619-623, 1998

77. Figueroa JA, Jackson JG, McGuire WL, Krywicki RF and Yee D: Expression of insulin-like growth factor binding proteins in human breast cancer correlates with estrogen receptor status. J Cell Biochem 52: 196-205, 1993.

78. McGuire SE, Hilsenbeck SG, Figueroa JA, Jackson JG and Yee D: Detection of insulin-like growth factor binding proteins (IGFBPs) by ligand blotting in breast cancer tissues. Cancer Lett 77: 25-32, 1994.

79. Chen JC, Shao ZM, Sheikh MS, Hussain A, Le Roith D, Roberts CT Jr and Fontana JA: Insulin-like growth factorbinding protein enhancement of insulin-like growth factor-I (IGF-I)-mediated DNA synthesis and IGF-I binding in a human breast carcinoma cell line. J Cell Physiol 158: 69-78, 1994.

80. Qin C, Singh $\mathrm{P}$ and Safe S: Transcriptional activation of insulinlike growth factor-binding protein-4 by 17 beta-estradiol in MCF-7 cells: role of estrogen receptor-Sp1 complexes. Endocrinology 140: 2501-2508, 1999

81. Coutts A, Murphy LJ and Murphy LC: Expression of insulinlike growth factor binding proteins by T-47D human breast cancer cells: regulation by progestins and antiestrogens. Breast Cancer Res Treat 32: 153-164, 1994.

82. Pratt SE and Pollak MN: Estrogen and antiestrogen modulation of MCF7 human breast cancer cell proliferation is associated with specific alterations in accumulation of insulin-like growth factor-binding proteins in conditioned media. Cancer Res 53: 5193-5198, 1993

83. Gronbaek H, Tanos V, Meirow D, Peretz T, Raz I and Flyvbjerg A: Effects of tamoxifen on insulin-like growth factors, IGF binding proteins and IGFBP-3 proteolysis in breast cancer patients. Anticancer Res 23: 2815-2820, 2003.

84. Huynh $\mathrm{H}$ : In vivo regulation of the insulin-like growth factor system of mitogens by human chorionic gonadotropin. Int $\mathrm{J}$ Oncol 13: 571-575,1998.

85. Adamo ML, Shao ZM, Lanau F, Chen JC, Clemmons DR, Roberts CT Jr, Le Roith D and Fontana JA: Insulin-like growth factor-I (IGF-I) and retinoic acid modulation of IGF-binding proteins (IGFBPs): IGFBP-2, -3 , and -4 gene expression and protein secretion in a breast cancer cell line. Endocrinology 131 . 1858-1866, 1992

86. Chambery D, De Galle B and Babajko S: Retinoic acid stimulates IGF binding protein (IGFBP)-6 and depresses IGFBP-2 and IGFBP-4 in SK-N-SH human neuroblastoma cells. J Endocrinol 159: 227-232, 1998.

87. Hofmann J, Wegmann B, Hackenberg R, Kunzmann R, Schulz KD and Havemann K: Production of insulin-like growth factor binding proteins by human ovarian carcinoma cells. J Cancer Res Clin Oncol 120: 137-142, 1994.
88. Neuvians TP, Gashaw I, Hasenfus A, Hacherhacker A, Winterhager E and Grobholz R: Differential expression of IGF components and insulin receptor isoforms in human seminoma versus normal testicular tissue. Neoplasia 7: 446-456, 2005.

89. Cheung C, Vesey D, Cotterill A, Douglas M, Gobe G, Nicol D and Johnson D: Altered messenger RNA and protein expressions for insulin-like growth factor family members in clear cell and papillary renal cell carcinomas. Int J Urol 12: $17-28,2005$.

90. Diehl D, Hoeflich A, Wolf E and Lahm H: Insulin-like growth factor (IGF)-binding protein-4 inhibits colony formation of colorectal cancer cells by IGF-independent mechanisms. Cancer Res 64: 1600-1603, 2004.

91. Park JH, Corkins MR, van der Hoof JA, Caruso NM, Hrbek MJ, Schaffer BS, Slentz DH, McCusker RH and MacDonald RG: Expression of insulin-like growth factor-II and insulin-like growth factor binding proteins during $\mathrm{Caco}-2$ cell proliferation and differentiation. J Cell Physiol 166: 396-406, 1996.

92. Hoeflich A, Yang Y, Huber S, Rascher W, Koepf G, Blum WF, Heinz-Erian P, Kolb HJ and Kiess W: Expression of IGFBP-2, -3 , and -4 mRNA during differentiation of Caco-2 colon epithelial cells. Am J Physiol 271: 922-931, 1996.

93. Singh P, Dai B, Dhruva B and Widen SG: Episomal expression of sense and antisense insulin-like growth factor (IGF)-binding protein-4 complementary DNA alters the mitogenic response of a human colon cancer cell line (HT-29) by mechanisms that are independent of and dependent upon IGF-I. Cancer Res 54: 6563-6570, 1994

94. Corkins MR, McQuade J, Schaffer BS and MacDonald RG: Insulin-like growth factor binding protein-4 expression is dependent on the carbohydrate in the media in HT-29 cells. Growth Horm IGF Res 12: 184-192, 2002.

95. Akagi Y, Liu W, Zebrowski B, Xie K and Ellis LM: Regulation of vascular endothelial growth factor expression in human colon cancer by insulin-like growth factor-I. Cancer Res 58: 4008-4014, 1998

96. Drivdahl RH, Loop SM, Andress DL and Ostenson RC: IGFbinding proteins in human prostate tumor cells: expression and regulation by 1,25-dihydroxyvitamin D3. Prostate 26: 72-79, 1995.

97. Drivdahl RH, Sprenger C, Trimm K and Plymate SR: Inhibition of growth and increased expression of insulin-like growth factor-binding protein-3 (IGFBP-3) and -6 in prostate cancer cells stably transfected with antisense IGFBP-4 complementary deoxyribonucleic acid. Endocrinology 142: 1990-1998, 2001

98. Scharf JG, Ramadori G and Dombrowski F: Analysis of the IGF axis in preneoplastic hepatic foci and hepatocellular neoplasms developing after low-number pancreatic islet transplantation into the livers of streptozotocin diabetic rats. Lab Invest 80: 1399-1411, 2000.

99. Ng EH, Ji CY, Tan PH, Lin V, Soo KC and Lee KO: Altered serum levels of insulin-like growth-factor binding proteins in breast cancer patients. Ann Surg Oncol 5: 194-201, 1998.

100. Lawrence JB, Conover CA, Haddad TC, Ingle JN, Reid JM, Ames MM, Suman VJ, Marks RS, Erlichman C and Hartmann LC: Evaluation of continuous infusion suramin in metastatic breast cancer: impact on plasma levels of insulinlike growth factors (IGFs) and IGF-binding proteins. Clin Cancer Res 3: 1713-1720, 1997.

101. Bernardini S, Cianfarani S, Spagnoli A, AnnicchiaricoPetruzzelli M, Melino G, Massoud R, Boscherini B, FinazziAgro A, Rosenfeld RG and Federici G: Expression and downregulation by retinoic acid of IGF binding protein- 2 and -4 in medium from human neuroblastoma cells. J Neuroendocrinol 6: 409-413, 1994

102. Cho HJ, Lee HS, Chung CK, Kang YH, Ha YL, Park HS and Park JH: Trans-10, cis-12 conjugated linoleic acid reduces insulin-like growth factor-II secretion in HT-29 human colon cancer cells. J Med Food 6: 193-199, 2003

103. Singh P, Dai B, Yallampalli U, Lu X and Schroy PC: Proliferation and differentiation of a human colon cancer cell line $(\mathrm{CaCo} 2)$ is associated with significant changes in the expression and secretion of insulin-like growth factor (IGF) IGF-II and IGF binding protein-4: role of IGF-II. Endocrinology 137: 1764-1774, 1996.

104. Culouscou JM and Shoyab M: Purification of a colon cancer cell growth inhibitor and its identification as an insulin-like growth factor binding protein. Cancer Res 51: 2813-2819, 1991. 